\title{
Germana Nicklin
}

\section{Uncertainty in Policy: implications for practice}

Introduction

Academics have been writing about uncertainty in public administration since the 1950s (Brown, 1978; Lindblom, 1959), and more recently complexity theory has provided tools for learning one's way through uncertainty (Eppel, Turner and Wolf, 2011; Kurtz and Snowden, 2003). Uncertainty is different from change. Uncertainty arises from change, but it is also an effect of the social interactions engaged in by public servants going about their business, and of the environment they work in. Research on the way policy is practised provides a way to 'understand how to conceive of public policy making in an uncertain world' (Hajer and Laws, in Moran, Rein and Goodin, 2006, p.421). Within this field, the pervasiveness of the effects of uncertainty on the daily work of policy practitioners appears to have been given less attention than it deserves.
This article aims to stimulate thinking about the positive and negative effects of uncertainty. It does not purport to have all the answers on how to manage uncertainty better; rather, it provides illustrative stories from my recent $\mathrm{PhD}$ research on the interplay between narrative and action in the domain of trans-Tasman border management. That research revealed that the working environment of policy officials is anything but stable; that uncertainty acts on officials and how they practice their work, day to day.

\section{The fragility of social connections}

The sociology of translation (more commonly known as actor-network theory), which has as its starting point the fragility of social connections, provides an entry point into the subject of uncertainty. To illustrate, Bruno Latour tells a story about Shirley Strum's study of baboons (Latour, 2007). Strum observed that baboon social relationships were complex, held together by agreed behaviours, such as grooming. She realised that grooming was not just a practical activity to clean the fur; it was a part of maintaining positive social connections. But she also observed that the baboons had to keep doing this every day to maintain the stability of those connections. In other words, the daily performance of those activities bound this baboon social group together.

However, unlike baboons, humans have been able to stabilise social connections through inventing mechanisms such as language, and the writing down of language; through creating processes and being able to document them for others to use; through building machines and organisations and 
infrastructures. Importantly, these have enabled us to transport ideas from one place to another. For example, the idea of public sector organisations providing advice to ministers and Cabinet has been translated into a written account of the method, which is transported by way of the Cabinet Office Manual.

Even so, Latour asserts that stabilising mechanisms are only temporary and will break down over time. We can see these breakdowns in the public sector all the time: Cave Creek and Pike River are extreme examples. However, we humans tend to behave as if our stabilising mechanisms are permanent, and when that stability breaks down we treat it as a problem. Bruno Latour reminds us that ' $\mathrm{t}]$ he world is not a solid continent of facts sprinkled by a few lakes of uncertainties, but a vast ocean of uncertainties speckled by a few islands of calibrated and stabilized forms' (Latour, 2007, p.245).

The following stories from my $\mathrm{PhD}$ thesis show how uncertainty unconsciously affected officials' actions, and highlight its impacts.

\section{Story 1: Cumulative change creating uncertainty of purpose}

Story 1 tells what happened to a transTasman Customs senior officials group called the High Level Steering Group. Created out of a Customs ministerial meeting in 2005, this group from Australia and New Zealand customs administrations, and on four occasions including the respective biosecurity administrations, met regularly until 2009, after which meetings started to tail off.

In the first few years the group was small, and while the meetings and work programme had structure, it was a light touch, enabling frank exchanges between the senior officials. At this time the group was co-chaired by two deputy chief executives who knew each other well. The group's focus was clear enough, its work programme generated results and its regular meetings, often with an annotated agenda and resulting action points, created an impetus for action. For example, on more than one occasion a trans-Tasman workshop addressing one of the action points from the previous minutes was held two weeks before the next group meeting.

In the later stages of the group, however, the purpose narrative lacked clarity. One official observed:

there were probably some people particularly in the High Level Steering Group that felt that the discussions weren't as valuable as they might have been and that it wasn't clear what the purpose of some of the agenda items was.

(Nicklin, 2015, p.150) resulting in a dropping off of impetus; the work emerging from a joint AustraliaNew Zealand prime ministerial statement on 2 March 2009, in effect overtaking the work of the group, which was not strongly connected into either organisation's strategic priorities. ${ }^{2}$ It is evident that the group was undergoing constant change, and the cumulative effect of that change was uncertainty of purpose.

Uncertainty of purpose is familiar in the policy world, particularly when officials have to translate ambiguous directional political statements into something actionable. One official

\section{Uncertainty of purpose is familiar in the policy world, particularly when officials have to translate ambiguous directional political statements into something actionable.}

Another raised questions about the future of the group, for which no answers were forthcoming:

Australian International ${ }^{1}$ had an action in probably about 2009 to review the HLSG in tandem with us, and that never really led to anything. So 'what was the role of the HLSG, what was the role of the two Customs agencies, where did our responsibilities lie, what did we want out of CEs, what did we want out of Ministers?' (Nicklin, 2015, p.150)

The data indicates that there were multiple factors leading to the uncertainty of purpose: one of the co-chairs retired, thus removing the close personal relationship that maintained the impetus of the group; the number of attendees at the meetings increased as people from lower levels in the organisation attended to report on their item, resulting in an inability to conduct the more intimate discussions originally intended; some items on the work programme were completed or found to be unfeasible, articulated the difficulty:

often what happens is you have that broad political statement, like the 2009 statement, and so officials get excited, try to come up with solutions to match that, and the solutions are a bit vague and unclear, and therefore in discussion we were never really sure between the two countries what we were actually trying to do. (Nicklin, 2015, p.181)

A common and usually effective response to uncertainty of purpose is to revisit and rework it, often through changing the narrative. ${ }^{3}$

\section{Story 2: Messy narratives}

A key aspect of policy practice is uncovering and telling a story (Roe, 1994). However, more than just being told, John Law sees stories as acting on us and enabling us to create things: 'one way of imagining the world is that it is a set of (pretty disorderly) stories that intersect and interfere with one another' (Law, 2000, p.2). He is talking about how 
messy the process of doing so often is, as different people's narratives rub up against one another. A side-effect of this messiness is uncertainty.

Story 2 tells of the uncertainty created by narratives that intersected and interfered with one another. On 2 March 2009 the Australian and New Zealand prime ministers committed, in their usual joint statement issued after meeting over the previous two days, to 'reduce remaining barriers at the borders to ensure that people and goods can move more easily between the two countries' (Key and Rudd, 2009a). One initiative supported by New Zealand prime minister John Key was for New Zealand to introduce SmartGate, the automated
The data shows that the process of agreeing on the exact narrative that accommodated these different matters of concern in the Cabinet paper caused considerable uncertainty for officials, particularly for Customs, who were holding the pen. Added pressures on officials were the tight time frame and Cabinet's directive to present a paper with a single set of recommendations.

This story highlights the uncertainty caused by agencies working together without having first sorted out their respective organisational narratives. My research showed that when officials work across agencies they bring to the table many different narratives, both individually and collectively. Some of

\section{The delivery time frame demanded by the DPMC acted on officials in this situation, making it impossible for them to trial or test any of the ideas beyond basic consultation with their operational colleagues.}

passenger processing technology introduced by Australia in 2007 - and now in operation at Auckland, Wellington and Christchurch international airports. Key wanted to see visible change by December that year, which made a tight time frame for getting Cabinet approval, then purchasing and installing the equipment. Customs' main narrative was that investing in SmartGate would create a common trans-Tasman experience for travellers: this was the driver for that particular technology choice. To them, they were just automating an existing process (implication: there's no problem). The other border agencies had different concerns. They wanted a good investment for government, one that could accommodate their longer-term needs and that would bring productivity and financial benefits. Their narratives were different. None was 'right' or 'wrong'. these narratives are implied rather than explicit, and can cause disruptions (and therefore uncertainties) later in the process if not flushed out. At the start of a policy initiative there could be benefit from taking more time to unpack the matters of concern that officials bring into the room, and the narratives that sit behind them, to see where those narratives contribute to the matter that brings people together, and where they conflict. This would then clear the way for officials to examine the 'who, what, when, where and how' of the work.

\section{Story 3: Uncertainty from tight deadlines}

Policy practitioners are used to working to tight deadlines. Story 3 describes the uncertainty from having to work to an extreme set of deadlines, and what officials did to meet them.

On 12 March 2009, ten days after the 2 March joint prime ministerial statement, the chief executive of the Department of the Prime Minister and Cabinet (DPMC) tasked New Zealand border agency ${ }^{4}$ officials with developing a new transTasman travel model for consideration by Cabinet. The officials were given a punishingly short time frame, having to produce a report to the chief executive of the DPMC in two weeks, and a proposal for the Cabinet strategy committee, with all its attendant sign-offs by senior officials and three border ministers, for a meeting five weeks later; a full Cabinet paper with proposals agreed by border agencies in New Zealand and Australia was to be completed six weeks after that.

The data shows the discomfort officials were experiencing at having to document how something would work when they had not had time to fully check out how or whether what they were saying would work. For example:

in an update on the outcome of a New Zealand Customs workshop I had facilitated, ${ }^{5}$ I noted '... another important conclusion was confirming that what we are proposing for $\mathrm{TT}^{6}$ is complex - we won't really know the effect of changing our processes so dramatically, so need to be able to test our assumptions as we go'. (Nicklin, 2015, p.176)

The delivery time frame demanded by the DPMC acted on officials in this situation, making it impossible for them to trial or test any of the ideas beyond basic consultation with their operational colleagues. At the same time,

dates were unstable - dates for papers to be discussed by Cabinet; dates of Ministers' meetings. In the former case, this had a positive effect by providing more time to develop the required detail; in the latter, it removed an opportunity to test New Zealand's thinking with Australia at the ministerial level. This would have reduced one area of uncertainty. (Nicklin, 2015, p.181)

A key mechanism for reducing the uncertainty and managing the pressure during this period was the border sector 
secretariat. This small team, whose role was to coordinate the collaborative work of the border sector agencies, issued a timeline of day-by-day actions, organised the many multi-agency meetings, drafted the papers, and interpreted the multiple sources of feedback on those drafts, turning them into an agreed final product. Tools such as email and a shared electronic workspace played important roles in transporting the meeting invitations, draft and final papers and feedback between officials.

The border secretariat did a lot more than just coordinate. Its staff and its outputs spoke on behalf of New Zealand border agencies and the DPMC, who in turn spoke on behalf of the prime minister. This created a thick set of connections for the border secretariat which helped them deliver a new model and a supporting Cabinet paper in a very short time frame. An effect of these connections, and the tight time frames they created, was the necessity to bypass a full policy process, which would have seen them consulting widely on and iterating the design of the model before submitting it to Cabinet. The stabilising effect of the secretariat could be seen as a kind of proxy for the effect a full policy process would have had in reducing uncertainty, though I suggest the full process would have reduced the uncertainty more.

This mechanism was disestablished in late 2011, when priorities changed and it was no longer seen to be needed. It was re-established recently as a new need emerged, highlighting the temporary nature of stabilising mechanisms, and reminding us that they need to be reviewed periodically for fitness for purpose.

Story 4: The uncertainty of the future and how to reduce it

On 20 August 2009 the two prime ministers issued a second joint prime ministerial statement which committed to a joint Australia-New Zealand feasibility study on a new trans-Tasman travel model (Key and Rudd, 2009b). This commitment reflected Australia's desire to start afresh because of different stakeholder interests in Australia, rather than use New Zealand's model. To make the work manageable, officials split it into two phases. Phase one was to develop terms of reference which set out different options, a wide range of considerations and an estimated budget; phase two was to develop from one of those options a model that provided a 'domestic-like experience'. Both phases were conducted by the same external contractor.

This work was slower in pace than that in Story 3, and the nature of the uncertainties was different. The purpose of the work was clear enough; the time frames were more manageable; the narratives of the different agencies involved on both sides of the Tasman were different but not disruptive. ${ }^{7}$ Uncertainty came from the physical separation of each off point for the next stage of detail. The diagrams were particularly important in providing a picture of the future that was communicable to others, with each new level of detail making the picture of the future more and more tangible.

These observations highlight that the concept of a 'future state' is invisible until it is revealed, and while it is being revealed, it is unstable. At the same time, through the policy process, each part is stabilised, albeit temporarily, as it is revealed. (Nicklin, 2015, p.219)

In doing so they made the future goal (the end) less and less uncertain,

\section{There is another side to uncertainty - that of an opening up, of creating a space for possibility.}

country's officials, lack of clarity around the problem to be solved, and the lack of something tangible with which senior officials could engage. Unlike SmartGate, which was a piece of technology that could be seen, touched and used, the work on the new model couldn't be easily experienced.

What officials did unconsciously was to step by step make the end goal more and more visible. The initial decision to maintain existing connections (i.e., travel being between two international airports, as opposed to options involving domestic airports) could be experienced, and so was easy to understand. However, how the new model would be different, and how it would work, was not. So officials defined and described the term 'domesticlike', and, as the work developed, created a representational diagram supported by a detailed description.

The descriptions and visual iterations of the model played an important part in creating stabilising points for the work. They gave officials something to present to senior officials for decision, each decision giving officials a stable jumping- although even seemingly stabilised points were sometimes relitigated. Eventually, officials had enough detail to be able to translate the description of the model into a question about the feasibility of implementing it: did the cost-benefit really stack up? This was the point at which the chief executives became properly engaged, because it connected with their core interests.

\section{Reflections}

Reflecting on these stories, we can see some wider implications from examining uncertainty. First, the effects of uncertainty on officials are part of what officials manage every day and manifest in multiple ways in their work. They help explain why the policy cycle is less a model that represents how policy works, and more a visual concept that helps provide some structure to policy practitioners' thinking.

Second, these stories reinforce that policy practice is an uncertain business, not just a changing or a risky business. Therefore, the more we can understand the effects of uncertainty on officials, and 
bring to light the ways in which those officials effectively counteract or manage those effects, the better the outcomes are going to be.

Third, uncertainty doesn't just affect the work; it affects the people carrying it out. For example, my research has shown how uncertainty can undermine officials' confidence in the advice they are providing; how it can create misunderstandings and emotions that derail the work; how it can result in officials not being clear about what they are meant to be delivering or why. These are effects that can be, and need to be, managed.

There is another side to uncertainty that of an opening up, of creating a space for possibility. For while something is uncertain, it is not set, and there is 'room for something different to occur' (Nicklin,
2015, p.259). The introduction of service design and continuous improvement methods into the public service speak to this 'possibility space' through new ways of working, a development worthy of further investigation.

Do we need a new way to look at uncertainty? Would we get different results, for example, if we practiced policy with an expectation of uncertainty and if we better understood how to deal with it; if we appreciated periods of stability, rather than expected them? These reflections and questions indicate that there is value in finding out more about how officials can better understand and manage the effects of uncertainty.

\footnotetext{
1 The International section in the Australian Customs and Border Protection Service, which looked after the bilateral relationship with New Zealand.
}

2 See Story 2

3 The terms 'narrative' and 'story' are used interchangeably, although stories are often equated with a 'beginning-middleend', whereas narratives are less so.

4 New Zealand Customs Service, Ministry of Agriculture and Forestry, Department of Labour (Immigration New Zealand), Department of Internal Affairs and Ministry of Transport. Australian border agencies were not involved in this work, though they were consulted briefly.

5 I was very involved in this particular initiative.

6 TT is short for trans-Tasman, referring to the work on the new travel model.

7 By comparison, some stakeholders were pushing for their own interests. For example, the Tourism and Transport Forum Australia wrote two reports - Special Treatment for a Special Relationship (August 2013) and Bringing our Neighbour Closer (August 2014) (retrieved from http://www.ttf.org.au/ Content/aviation.asp) - and a media article (retrieved from http://www.scoop.co.nz/stories/BU0905/S00097.htm).

Disclaimer: The views in this article are the author's own, and do not represent the position of the New Zealand Customs Service or the New Zealand government.

\section{References}

Brown, R.H. (1978) 'Bureaucracy as praxis: toward a political phenomenology of formal organizations', Administrative Science Quarterly, (3), pp.365-82, http://doi.org/dx.doi.10.2307/2392415

Eppel, E.A., D. Turner and A. Wolf (2011) Experimentation and Learning in Policy Implementation: implications for public management, working paper 11/04. Wellington: Institute of Policy Studies, http://ips.ac.nz/ publications/publications/show/317

Key, J. and K. Rudd (2009a) 'Key and Rudd - joint statement on strengthened trans-Tasman cooperation', 2 March, http://www. beehive.govt.nz/release/joint-statement-strengthened-ns-tasmancooperation, accessed 25 May 2013

Key, J. and K. Rudd (2009b) 'Joint statement by Prime Ministers Rudd and Key', 20 August, http://www.beehive.govt.nz/release/jointstatement-prime-ministers-rudd-and-key

Kurtz, C.F. and D.J. Snowden (2003) 'The new dynamics of strategy: sense-making in a complex and complicated world', IBM Systems Journal, 42 (3), pp.462-83, http://doi.org/10.1147/sj.423.0462
Latour, B. (2007) Reassembling the Social: an introduction to actornetwork theory (new edn), Oxford: Oxford University Press

Law, J. (2000) 'On the subject of the object: narrative, technology, and interpellation', Configurations, 8 (1), pp.1-29

Lindblom, C.E. (1959) 'The science of "muddling through"', Public Administration Review, 19 (2), pp.79-88

Moran, M., M. Rein and R.E. Goodin (eds) (2006) The Oxford Handbook of Public Policy, Oxford: Oxford University Press

Nicklin, G. (2015) 'Trans-tasman border stories: actor-network theory and policy narrative in action', PhD thesis, Victoria University of Wellington, http://researcharchive.vuw.ac.nz/ handle/10063/4704?show =full

Roe, E. (1994) Narrative Policy Analysis, Durham, NC: Duke University Press

\section{Where Does Liberty Thrive? P The ecological origins of democracy and autocracy \\ Stephen Haber \\ Senior Fellow and Professor \\ at Stanford University \\ Monday 23rd November 12:30 - 1:30pm \\ Old Government Buildings Lecture Theatre \\ 3 (Ground floor) \\ RSVPs not required. \\ See more at igps.victoria.ac.nz

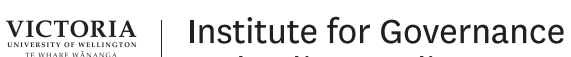 A}

